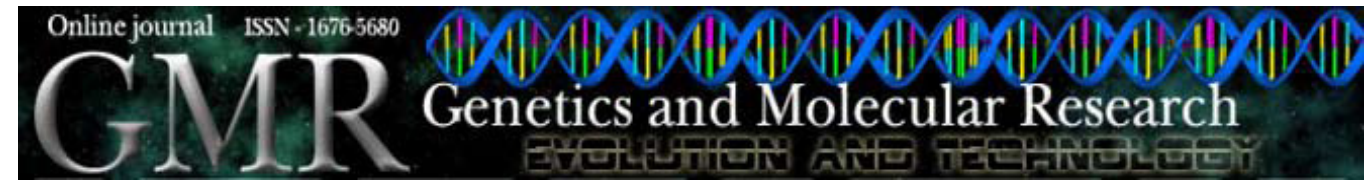

\title{
Meta-analysis of epidemiological studies of association of P53 codon 72 polymorphism with bladder cancer
}

\author{
D.B. Li ${ }^{1,2}$, X. Wei ${ }^{2}$, L.H. Jiang ${ }^{2}$, Y. Wang ${ }^{2,3}$ and F. Xü ${ }^{2}$ \\ ${ }^{1}$ Department of Urology, First Affiliated Hospital of Zunyi Medical College, \\ Zunyi, Guizhou, China \\ ${ }^{2}$ Department of Urology, West China Hospital, \\ Sichuan University, Chengdu, Sichuan, China \\ ${ }^{3}$ Department of Urology, Third Affiliated Hospital of Zunyi Medical College, \\ Zunyi, Guizhou, China \\ Corresponding author: D.B. Li \\ E-mail: daobingli@hotmail.com
}

Genet. Mol. Res. 9 (3): 1599-1605 (2010)

Received May 15, 2010

Accepted June 11, 2010

Published August 17, 2010

DOI 10.4238/vol9-3gmr882

\begin{abstract}
Although there have been many studies investigating a possible association between p53 codon 72 polymorphism and risk of bladder cancer, the results have been inconsistent. We conducted a meta-analysis of six epidemiological studies, which included 597 bladder cancer cases and 731 controls. Patients with bladder cancer had a significantly lower frequency of Pro/Arg [odds ratio $(\mathrm{OR})=0.80$, $95 \%$ confidence interval $(\mathrm{CI})=0.64-0.99]$, when compared to controls. Stratifying for race, we found that among Caucasians, patients with bladder cancer had a significantly higher frequency of Arg/Arg $(\mathrm{OR}=$ $1.64,95 \% \mathrm{CI}=1.18-2.28)$ and a lower frequency of $\mathrm{Pro} / \mathrm{Arg}(\mathrm{OR}=0.62$, $95 \% \mathrm{CI}=0.44-0.86)$, compared to controls. Stratifying various studies by the stage of bladder cancer, we found that invasive bladder cancers had a significantly lower frequency of $\mathrm{Arg} / \mathrm{Arg}(\mathrm{OR}=0.58,95 \% \mathrm{CI}=$ $0.36-0.93)$ and a higher frequency of $\operatorname{Pro} / \operatorname{Arg}(\mathrm{OR}=0.62,95 \% \mathrm{CI}=0.44$ $0.86)$ than did non-invasive bladder cancers. No significant association
\end{abstract}


was found between this genotype and human papilloma virus. Based on our meta-analysis, we suggest that p53 codon 72 polymorphism is associated with bladder cancer and that genotypic distribution of this polymorphism varies with the stage of bladder cancer.

Key words: Bladder cancer; p53 codon 72; Gene polymorphism; Meta-analysis

\section{INTRODUCTION}

Bladder cancer is the second most common genitourinary malignant disease in the USA, with an expected 69,000 newly diagnosed cases in 2008, and 14,000 deaths (Jemal et al., 2008). Risk factors for the development of bladder cancer can be classified into three subsets: genetic and molecular abnormalities, chemical or environmental exposures, and chronic irritation. Genetic and molecular factors include oncogenes, tumor suppressor genes, and those newly implicated such as the fragile histidine triad gene (Kaufman et al., 2009). Of all newly diagnosed cases of bladder cancer, about $70 \%$ present as superficial tumors, but as many as $50-70 \%$ of those superficial tumors will recur, and roughly $10-20 \%$ will progress to muscularis propria invasive disease (Rubben et al., 1988). To predict which patients will progress from superficial to muscularis propria invasive disease remains a challenge (Kaufman et al., 2009)

Over the past decade, polymorphism at codon 72 of the TP53 gene (Pro72Arg; rs1042522) has been investigated. Three genotypes occur: arginine homozygotes (Arg/Arg), proline homozygotes (Pro/Pro), and heterozygotes (Pro/Arg) (Klug et al., 2009). A guanine/cytosine variant at the second position of codon 72 on exon 4 leads to Arg 72 or Pro 72 protein variants with markedly altered primary structures and different biochemical functions. The current view is that the P53Arg72 protein is more effective than the P53-Pro72 protein at inducing apoptosis and protecting cells from tumor development. The P53 tumor-suppressor protein has been called the guardian of human cells against cancer (Hollstein et al., 1991). P53 is a nuclear protein that induces cell cycle arrest, apoptosis, inhibition of angiogenesis, metastasis, and DNA repair (Levine, 1997). P53 codon 72 polymorphisms have been reported to be associated with cancers of the stomach (Zhou et al., 2007), esophagus (Lee et al., 2006), colorectum (Koushik et al., 2006), lung (Matakidou et al., 2003), breast (Tommiska et al., 2005), and cervix (Klug et al., 2009).

Although there have been many studies investigating a possible association between p53 codon 72 polymorphism and risk of bladder cancer, the results have been inconsistent. We conducted a meta-analysis to assess whether a relationship exists between p53 codon 72 polymorphism and risk of bladder cancer.

\section{METHODS}

\section{Literature search}

We searched various databases including PubMed, Embase, and the Cochrane Library to identify studies on $\mathrm{p} 53$ polymorphism and bladder cancer published before 2010 . The following key words were used: 'p53' or 'codon 72', 'bladder', 'carcinoma' or 'cancer' or 'tumor'. The reference lists of reviews and retrieved articles were handsearched at the same time. 
We did not consider abstracts or unpublished reports. All studies on p53 polymorphism and bladder cancer published before 2010 were included. No language restrictions were applied; all non-English articles were translated if necessary.

\section{Selection criteria}

Titles and abstracts of all citations and retrieved studies were reviewed by two independent researchers. To be eligible for inclusion, studies had to be case-control that reported genotypic frequencies for both case and control populations. Interim analyses, overlapping study populations, and comparisons of laboratory methods were excluded.

\section{Statistical analysis}

We imported data into STATA, version 9.2 (Stata Corporation, College Station, TX, USA). To determine whether to use the fixed- or random-effects models, we measured statistical heterogeneity between and within groups using the Q-statistic, where $\mathrm{P}<0.05$ was considered to be statistically significant. Heterogeneity was also assessed through visual examination of L'Abbe plots. We used fixed-effects methods if the result of the Q-test was not significant. Otherwise, we calculated pooled estimates and confidence intervals, assuming a random-effects model. While publication bias was not expected, we assessed this possibility using Begg funnel plots and Egger's bias test (Begg and Mazumdar, 1994; Egger et al., 1997). We calculated separate pooled estimates for different ethnic groups and geographic regions. Subgroup analysis was conducted on the basis of race, human papilloma virus (HPV) and the stage of bladder cancer.

\section{RESULTS}

Six studies were included in the meta-analysis (Chen et al., 2000; Toruner et al., 2001; Soulitzis et al., 2002; Mabrouk et al., 2003; Horikawa et al., 2008; Murgel de Castro Santos et al., 2009), for a total of 1328 subjects (597 bladder cancer cases and 731 controls). Table 1 provides the general characteristics of the studies. Of these studies, three reported on Caucasians, two reported on Asians, and one reported on Africans.

\begin{tabular}{|c|c|c|c|c|c|c|c|c|c|c|c|c|}
\hline $\begin{array}{l}\text { Study } \\
\text { (author, year) }\end{array}$ & Design & $\begin{array}{l}\text { Study } \\
\text { period }\end{array}$ & $\begin{array}{c}\text { Population } \\
\text { (country) }\end{array}$ & $\begin{array}{c}\text { Genotyping } \\
\text { method }\end{array}$ & $\begin{array}{l}\text { No. of } \\
\text { cases }\end{array}$ & $\begin{array}{l}\text { No. of } \\
\text { controls }\end{array}$ & $\begin{array}{c}\mathrm{Arg} / \mathrm{Arg} \\
\text { cases }\end{array}$ & $\begin{array}{c}\text { Pro/Arg } \\
\text { cases }\end{array}$ & $\begin{array}{c}\text { Pro/Pro } \\
\text { cases }\end{array}$ & $\begin{array}{l}\text { Arg/Arg } \\
\text { controls }\end{array}$ & $\begin{array}{l}\text { Pro/Arg } \\
\text { controls }\end{array}$ & $\begin{array}{l}\text { Pro/Pro } \\
\text { controls }\end{array}$ \\
\hline Chen et al., 2000 & $\mathrm{HCC}$ & 1998-1999 & Asians (China) & PCR & 58 & 59 & 26 & 25 & 7 & 25 & 26 & 8 \\
\hline Toruner et al., 2001 & $\mathrm{HCC}$ & $\mathrm{nr}$ & Caucasians (Turkey) & PCR & 121 & 114 & 43 & 57 & 21 & 42 & 55 & 17 \\
\hline Soulitzis et al., 2002 & PCC & $\mathrm{nr}$ & Caucasians (Greece) & PCR & 50 & 99 & 30 & 18 & 2 & 24 & 64 & 11 \\
\hline Mabrouk et al., 2003 & $\mathrm{PCC}$ & $\mathrm{nr}$ & Africans (Tunisia) & PCR-RFLP & 47 & 34 & 21 & 23 & 3 & 13 & 19 & 2 \\
\hline Horikawa et al., 2008 & $3 \mathrm{HCC}$ & 1990-2004 & Asians (Japan) & PCR & 227 & 266 & 73 & 118 & 36 & 93 & 136 & 38 \\
\hline Murgel et al., 2009 & PCC & $\mathrm{nr}$ & Caucasians (Brazil) & PCR-RFLP & 94 & 159 & 64 & 24 & 6 & 90 & 60 & 9 \\
\hline
\end{tabular}

$\mathrm{HCC}=$ hospital-based case-control; $\mathrm{PCC}=$ population-based case-control; $\mathrm{nr}=$ not reported; $\mathrm{PCR}=$ polymerase chain reaction; RFLP = restriction fragment length polymorphism.

The combined results based on all studies showed that patients with bladder cancer had a significantly lower frequency of Pro/Arg [odds ratio $(\mathrm{OR})=0.80,95 \%$ confidence inter$\operatorname{val}(\mathrm{CI})=0.64-0.99]$ than did controls. When stratifying for race, we found that among Cau- 
casians, patients with bladder cancer had a significantly higher frequency of $\operatorname{Arg} / \operatorname{Arg}(\mathrm{OR}=$ $1.64,95 \% \mathrm{CI}=1.18-2.28)$ and a lower frequency of Pro/Arg $(\mathrm{OR}=0.62,95 \% \mathrm{CI}=0.44-0.86)$ compared to controls (Figures 1-3).

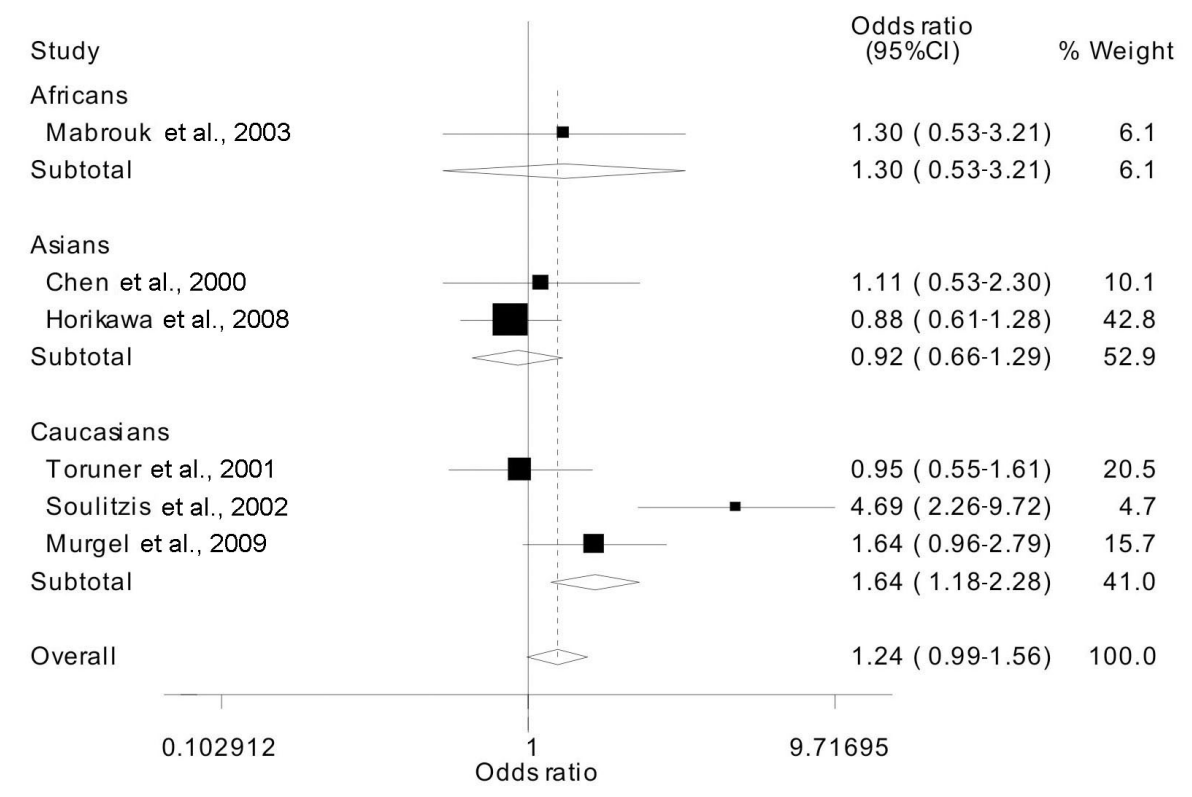

Figure 1. Meta-analysis of p53 codon 72 Arg/Arg and bladder cancer risk.

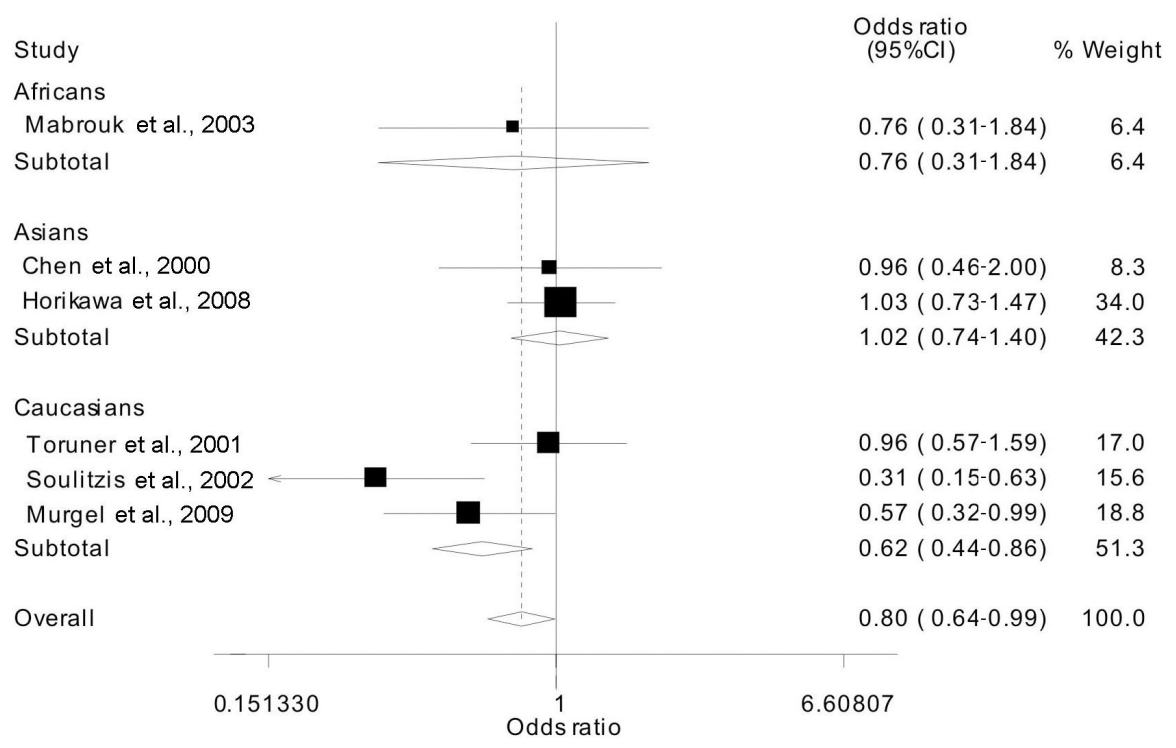

Figure 2. Meta-analysis of p53 codon 72 Pro/Arg and bladder cancer risk. 


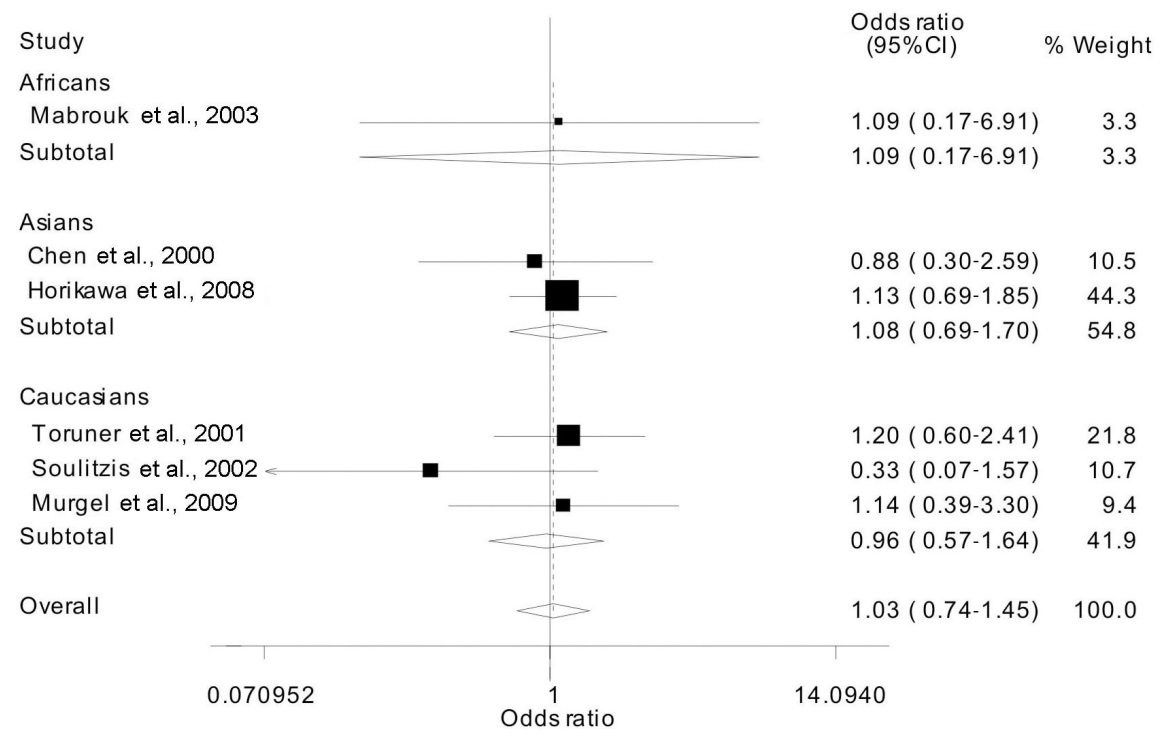

Figure 3. Meta-analysis of p53 codon 72 Pro/Pro and bladder cancer risk.

Stratifying the various studies by the stage of bladder cancer, we found that the invasive bladder cancers had a significantly lower frequency of $\mathrm{Arg} / \mathrm{Arg}(\mathrm{OR}=0.58,95 \% \mathrm{CI}=0.36-0.93)$ and a higher frequency of Pro/Arg $(\mathrm{OR}=1.36,95 \% \mathrm{CI}=0.45-4.16)$ than did the non-invasive bladder cancers. No statistical association was found between this genotype and HPV (Table 2).

\begin{tabular}{|c|c|c|c|c|c|c|c|}
\hline Stratification of bladder cancer & $\begin{array}{l}\text { No. of } \\
\text { studies }\end{array}$ & $\begin{array}{c}\text { OR }(95 \% \mathrm{CI}) \\
\text { of } \mathrm{Arg} / \mathrm{Arg}\end{array}$ & $\begin{array}{c}\mathrm{P} \text { for } \\
\text { heterogeneity }\end{array}$ & $\begin{array}{c}\text { OR }(95 \% \mathrm{CI}) \\
\text { of Pro/Arg }\end{array}$ & $\begin{array}{c}\mathrm{P} \text { for } \\
\text { heterogeneity }\end{array}$ & $\begin{array}{c}\text { OR }(95 \% \mathrm{CI}) \\
\text { of Pro/Pro }\end{array}$ & $\begin{array}{c}\text { P for } \\
\text { heterogeneity }\end{array}$ \\
\hline Stage: Invasive versus non-invasive & 3 & $0.58(0.36-0.93)$ & 0.06 & $1.36(0.45-4.16)$ & 0.04 & $1.95(1.10-3.46)$ & 1.00 \\
\hline Asians & 2 & $0.40(0.22-0.73)$ & 0.001 & $2.25(0.44-11.44)$ & 0.01 & $2.00(0.99-4.06)$ & 0.08 \\
\hline Caucasians & 1 & $1.26(0.55-2.87)$ & na & $0.55(0.24-1.24)$ & na & $1.85(0.69-4.97)$ & na \\
\hline HPV: Positive versus negative & 1 & $3.80(0.41-35.28)$ & na & $0.32(0.03-2.96)$ & na & na & na \\
\hline Asians & 0 & & & & & & \\
\hline Caucasians & 1 & $3.80(0.41-35.28)$ & na & $0.32(0.03-2.96)$ & na & na & na \\
\hline
\end{tabular}

$\mathrm{OR}=$ odds ratio; $\mathrm{CI}=$ confidence interval; $\mathrm{na}=$ not applicable; $\mathrm{HPV}=$ human papilloma virus.

\section{DISCUSSION}

Although several studies have investigated the association between p53 codon 72 polymorphism and risk of bladder cancer in the last ten years, small studies of genetic associations often have insufficient power, increasing the risk that chance could be responsible for their conclusions. Combining data from many studies has the advantage of reducing random error (Ioannidis et al., 2008). Meta-analysis enabled us to apply the same kind of criteria to all the study datasets and to obtain precise estimates for subgroups. Our meta-analysis of 1328 subjects from 6 studies provides evidence that $\mathrm{p} 53$ codon 72 polymorphism may be associated with bladder cancer, and that differences in genotype distribution may be associated with the stage of bladder cancer, described for the first time. 
Many studies have examined the association between 553 codon 72 polymorphisms and other cancers. To explore the true association between p53 codon 72 polymorphism and lung cancer risk, Dai et al. (2009) conducted a pooled analysis of 32 case-control studies involving 19,255 subjects. Their results suggested that the Pro allele at p53 codon 72 was emerging as a low-penetrance susceptibility allele for lung cancer development. The meta-analysis by Zhou et al. (2007) suggested that p53 codon 72 polymorphism may be associated with gastric cancer among Asians, and that differences in genotype distribution may be associated with the location, stage, and histological differentiation of gastric cancer. The meta-analysis by Sousa et al. (2007) revealed that the p53 Arg/Arg genotype did not seem to represent a risk marker for the development of cervical lesions in the majority of the European countries studied. However, in countries with low incidence rates of cervical cancer, this polymorphism could represent a significant genetic marker.

No statistical association was found between this genotype and HPV in our metaanalysis. Soulitzis et al. (2002) examined tumor specimens from all bladder cancer patients for the presence of HPV. HPV was detected in $12 \%$ of tumor specimens, which is consistent with previous studies performed in bladder cancer, confirming that HPV is a significant factor in the development of a small percent of tumors (Maloney et al., 1994; Lopez-Beltran et al., 1996; Simoneau et al., 1999). The lack of a statistical association between HPV infection and the homozygous p53Arg genotype in bladder cancer supports the synergistic action of the virus, especially in an environment with exposure to carcinogens, rather than its causative role in the development of the disease.

Our study has a number of possible limitations. First, the database for the meta-analysis included limited numbers of studies on ethnic groups; only two studies reported on Asians and only one study reported on Africans, reflecting the current lack of epidemiologic studies in these populations. Second, only published studies were included in the meta-analysis; therefore, publication bias may have occurred. Third, this meta-analysis is based on unadjusted estimates, while a more precise analysis could be performed if individual data were available. Another potential limitation was the small sample size in the analyses. Therefore, the power in the analyses was not sufficient to detect small increased risks. Finally, meta-analysis remains a retrospective research that is subject to the methodological deficiencies of the studies included.

To our knowledge, this is the first meta-analysis as a quantitative summary of the evidence for p53 codon 72 polymorphism and bladder cancer risk. This analysis supports conclusions that $\mathrm{p} 53$ codon 72 polymorphism may be associated with bladder cancer, and that differences in genotype distribution may be associated with the stage of bladder cancer. These findings warrant larger studies to clarify the role of p53 codon 72 polymorphism and to evaluate gene-environment interactions for $\mathrm{p} 53$.

\section{REFERENCES}

Begg CB and Mazumdar M (1994). Operating characteristics of a rank correlation test for publication bias. Biometrics 50: 1088-1101.

Chen WC, Tsai FJ, Wu JY, Wu HC, et al. (2000). Distributions of p53 codon 72 polymorphism in bladder cancer-proline form is prominent in invasive tumor. Urol. Res. 28: 293-296.

Dai S, Mao C, Jiang L, Wang G, et al. (2009). p53 polymorphism and lung cancer susceptibility: a pooled analysis of 32 case-control studies. Hum. Genet. 125: 633-638.

Egger M, Davey SG, Schneider M and Minder C (1997). Bias in meta-analysis detected by a simple, graphical test. BMJ 315: 629-634.

Genetics and Molecular Research 9 (3): 1599-1605 (2010)

CFUNPEC-RP www.funpecrp.com.br 
Hollstein M, Sidransky D, Vogelstein B and Harris CC (1991). p53 mutations in human cancers. Science 253: 49-53.

Horikawa Y, Nadaoka J, Saito M, Kumazawa T, et al. (2008). Clinical implications of the MDM2 SNP309 and p53 Arg72Pro polymorphisms in transitional cell carcinoma of the bladder. Oncol. Rep. 20: 49-55.

Ioannidis JP, Boffetta P, Little J, O'Brien TR, et al. (2008). Assessment of cumulative evidence on genetic associations: interim guidelines. Int. J. Epidemiol. 37: 120-132.

Jemal A, Siegel R, Ward E, Hao Y, et al. (2008). Cancer statistics, 2008. CA Cancer J. Clin. 58: 71-96.

Kaufman DS, Shipley WU and Feldman AS (2009). Bladder cancer. Lancet 374: 239-249.

Klug SJ, Ressing M, Koenig J, Abba MC, et al. (2009). TP53 codon 72 polymorphism and cervical cancer: a pooled analysis of individual data from 49 studies. Lancet Oncol. 10: 772-784.

Koushik A, Tranah GJ, Ma J, Stampfer MJ, et al. (2006). p53 Arg72Pro polymorphism and risk of colorectal adenoma and cancer. Int. J. Cancer 119: 1863-1868.

Lee JM, Shun CT, Wu MT, Chen YY, et al. (2006). The associations of p53 overexpression with p53 codon 72 genetic polymorphism in esophageal cancer. Mutat. Res. 594: 181-188.

Levine AJ (1997). p53, the cellular gatekeeper for growth and division. Cell 88: 323-331.

Lopez-Beltran A, Escudero AL, Vicioso L, Munoz E, et al. (1996). Human papillomavirus DNA as a factor determining the survival of bladder cancer patients. Br. J. Cancer 73: 124-127.

Mabrouk I, Baccouche S, El-Abed R, Mokdad-Gargouri R, et al. (2003). No evidence of correlation between p53 codon 72 polymorphism and risk of bladder or breast carcinoma in Tunisian patients. Ann. N. Y. Acad. Sci. 1010: 764-770.

Maloney KE, Wiener JS and Walther PJ (1994). Oncogenic human papillomaviruses are rarely associated with squamous cell carcinoma of the bladder: evaluation by differential polymerase chain reaction. J. Urol. 151: 360-364.

Matakidou A, Eisen T and Houlston RS (2003). TP53 polymorphisms and lung cancer risk: a systematic review and metaanalysis. Mutagenesis 18: 377-385.

Murgel de Castro Santos LE, Trindade Guilhen AC, Alves de AR, Garcia SL, et al. (2009). The role of TP53 Pro47Ser and Arg72Pro single nucleotide polymorphisms in the susceptibility to bladder cancer. Urol. Oncol. (in press). DOI: 10.1016/j.urolonc.2009.03.026.

Rubben H, Lutzeyer W, Fischer N, Deutz F, et al. (1988). Natural history and treatment of low and high risk superficial bladder tumors. J. Urol. 139: 283-285.

Simoneau M, LaRue H and Fradet Y (1999). Low frequency of human papillomavirus infection in initial papillary bladder tumors. Urol. Res. 27: 180-184.

Soulitzis N, Sourvinos G, Dokianakis DN and Spandidos DA (2002). p53 codon 72 polymorphism and its association with bladder cancer. Cancer Lett. 179: 175-183.

Sousa H, Santos AM, Pinto D and Medeiros R (2007). Is the p53 codon 72 polymorphism a key biomarker for cervical cancer development? A meta-analysis review within European populations. Int. J. Mol. Med. 20: 731-741.

Tommiska J, Eerola H, Heinonen M, Salonen L, et al. (2005). Breast cancer patients with p53 Pro 72 homozygous genotype have a poorer survival. Clin. Cancer Res. 11: 5098-5103.

Toruner GA, Ucar A, Tez M, Cetinkaya M, et al. (2001). p53 codon 72 polymorphism in bladder cancer - no evidence of association with increased risk or invasiveness. Urol. Res. 29: 393-395.

Zhou Y, Li N, Zhuang W, Liu GJ, et al. (2007). p53 codon 72 polymorphism and gastric cancer: a meta-analysis of the literature. Int. J. Cancer 121: 1481-1486. 